\title{
Н. Хмель
}

\section{ОСОБЛИВОСТІ ПЕРЕКЛАДЕННЯ ПАРТІЇ АРФИ ДЛЯ БАНДУРИ (НА ПРИКЛАДІ «КОНЦЕРТУ ДЛЯ ОРГАНУ (АБО АРФИ) ТА СТРУННОГО ОРКЕСТРУ В-duг» Г. Ф. ГЕНДЕЛЯ)}

В статті пропонується музично-виконавський аналіз другої частини «Концерту для органу (або арфи) та струнного оркестру B-dur» Г. Ф. Генделя в перекладенні для арфи та фортепіано М. Г. Парфенова та перекладенні для бандури та фортепіано Я. Г. Пухальського. Також розглядається специфіка трансформації партії арфи для бандури і розглядаються всі можливості такого перекладення.

Ключові слова: теорія виконавства творів епохи бароко, арфа, бандура, перекладення, трансформація, каденція.

Бандура увійшла в родину академічних інструментів лише в середині XX сторіччя, але іiі технічні та тембральні можливості розвиваються в досить швидкому темпі. На сьогоднішній день виконання на бандурі творів зарубіжних композиторів, починаючи від епохи бароко та класицизму, значно збагатили іiі репертуар. Тим більша, що тембральний окрас бандури дуже схожий з клавесином, одним з провідних інструментів зазначених епох.Виконавська практика доводить, що складна поліфонічна та гомофонно-гармонічна фактура епохи бароко у бандурному звучанні набуває нову якість, змістовно збагачується.

Перекладення та виконання творів різних жанрів і використання їх у навчально-виховному процесі цікавила багатьох дослідників. Йдеться про роботи: І. І. Дмитрук «Жанр перекладу та його різновиди в сучасному бандурному мистецтві» [5]; М. А. Давидова «Теоретичні основи перекладення інструментальних творів для баяна» [3]; В. Дутчак «Розвиток професійних засад бандурного мистецтва 1970-1990 років» [7]; В. Дейнега «Перекладення як процес переосмислення засобів оркестрової виразності» [4] тощо; С. В. Овчарова «До проблеми перекладення органних хоральних прелюдій Й. С. Баха в контексті динаміки подальшого розвитку сучасного бандурно-академічного репертуару» [8]; Н. В. Хмель «Специфика трансформации концерта c-moll Б. Марчелло - И. С. Баха в переложении для бандуры» [10].

Актуальність даної статті обумовлена можливістю перекладення та виконання творів епохи бароко, написаних для арфи або органу (арфи) на сучасному академічному інструменті - бандурі. 
Мета дослідження - показ можливостей збагачення бандурного репертуару творами епохи бароко.

Об'єкт дослідження - порівняння виконавських тенденцій епохи бароко та сучасності.

Предмет дослідження - «Концерт для органу (або арфи) та струнного оркестру B-dur» Г. Ф. Генделя та його порівняльна характеристика з перекладенням М. Г. Парфенова для арфи та фортепіано та перекладенням Я. Г. Пухальського для бандури та фортепіано.

Матеріал дослідження - «Концерт для органу (або арфи) та струнного оркестру B-dur» Г. Ф. Генделя в перекладенні для арфи та фортепіано М. Г. Парфенова та перекладенні для бандури та фортепіано Я. Г. Пухальського.

Микола Гаврилович Парфенов (1893-1942) отримав освіту в придворній співацькій капелі (клас викладача Шолара) та Московській консерваторії (клас викладача Слєпушкіна). Грав в оркестрах оперного театру Зіміна та Великого театру. Також багато часу та творчих сил віддавав вихованню учнів у Московській консерваторії (1925-1938), серед яких артистки оркестру Великого театру - М. Низковська, заслужена артистка республіки, доцент К. Сараджева, А. Ельдарова, а також заслужений діяч культури РРФСР, доцент М. Мчєдєлов та М. Рубін. На основі методичних записок Слєпушкіна Парфенов опублікував брошуру «Техника игры на арфе», а пізніше, доповнивши іiі, створив «Школу игры на арфе», яка була видана під редакцією М. Мчєдєлова. Він написав ряд творів для арфи, серед яких Концерт, етюди тощо [6, с. 107].

Ян Генріхович Пухальський - талановитий гітарист, викладач, методист, майстер-реставратор, дослідник (1923-1979). Навчався у вечірній музичній школі (1938), музичному училищі (1939-1941), Київській консерваторії (1944-1949), аспірантурі (1956-1959, клас викладача М. М. Геліса). Працював вихователем Боярського дитбудинку (1939-1941), солістом оркестру народних інструментів Українського радіо (1947-1949), старшим викладачем Молдавської консерваторії (1949-1956), солістом Українського гастрольно-концертного об’єднання і Українського радіо, ансамблістом Державного симфонічного оркестру. 31959 року - викладач кафедри народних інструментів Київської консерваторії - старший викладач гітари та бандури, куратор академгрупи (1956), доцент (1979).

Проводив у кінці 50-х та в 60 -х роках регулярну концертну діяльність, виступав у радіо- і телепрограмах, в урядових концертах. Видав 
понад 50 друкованих аркушів перекладень та редакцій музичних творів для гітари, понад 30 друкованих аркушів залишилося в рукописах. Автор підручників та методичних розробок «Методика викладання гри на бандурі» (1978), «Методика викладання гри на гітарі» (рукопис), «Збірник етюдів для гітари» (рукопис). Серед незавершених праць - дослідження з історії виконавських стилів гітарного мистецтва. Належав до талановитих майстрів-реставраторів скрипок, виготовляв гітари та інші музичні інструменти [2, с. 76].

Арфа та бандура мають велику кількість розрізнень (арфа - світський, бандура - народний інструмент), але в них є і спільні риси: історія виникнення обох інструментів бере свій початок від народних традицій; сучасна бандура має багато спільних рис з арфою народів Ірландії, Шотландії та Уельсу; вони відносяться до категорії струнно-щипкових інструментів; мають схожі тембральні характеристики; діапазон бандури приблизно співпадає з діапазоном арфи; використовуються спільні прийоми гри та штрихи [9]. Тому перекладати арфові твори для бандури досить зручно.

Концерт Г. Ф. Генделя написаний для соліста в якості органу або арфи без будь-якого уточнення одного виконавського варіанту, ми розглядаємо його як концерт для сколюючого інструменту - арфи. Слід зазначити, що хоча орган та арфа інструменти - антиподи, тим не менше, можливо деякі твори, створені для органу, інтерпретувати на арфі. У зв'язку з цим ми зупиняємось на варіанті концерту Г. Ф. Генделя В-dur для арфи. Зберігши Генделевську партію арфи, М. Г. Парфенов трансформує партію струнного оркестру в партію фортепіано, а пізніше Я. Г. Пухальський робить перекладення партії арфи для бандури. Таким чином, ми аналізуємо трьохваріантне перекладення - Г. Ф. Генделя, М. Г. Парфенова та Я. Г. Пухальського.

У якості прикладу перекладення музики бароко для сучасного інструменту ми зробимо музично-виконавський аналіз другої частини «Концерту для органу (або арфи) та струнного оркестру B-dur» Г. Ф. Генделя в перекладенні М. Г. Парфенова для арфи та фортепіано та перекладенні для бандури та фортепіано Я. Г. Пухальського.

Зробимо аналіз цього твору з позиції структури циклу, форми написання частин концерту. Концерт B-dur є традиційним для творчості Г. Ф. Генделя за будовою трьохчастинного циклу, причому всі частини створені в сонатній формі різного типу і виконуються без перерви - attacca. 
1. Allegro moderato. B-dur. Сонатна форма. 4/4.

2. Larghetto. g-moll. Сонатна форма. s.

3. Allegro non troppo. B-dur. Сонатна форма. 6/8.

Ми зупиняємося на другій частині Концерту - Larghetto (характерній для середніх частин циклічних форм Генделя), бо слід мати на увазі, що ця частина концерту найбільш красива та натхненна.

Також ця частина найбільш цікава з точки зору складу партії арфи та має розгорнуту, можна сказати, віртуозну «вставну» Каденцію, створену автором перекладання «Концерту для арфи та фортепіано» М. Г. Парфеновим для солюючого тут інструменту - арфи та Я. Г. Пухальським для бандури.

Таке введення Каденції робить більш значною середню частину твору, надає другій частині циклу нову драматургічну акцентованість, важливу змістовність, сприяє більшому драматургічному навантаженню в порівнянні з першоджерелом.

Показова Каденція концерта і тим, що автор перекладення, крім опори на концертну інтонаційність, використовує імпровізаційність - як принцип іiі створення, відроджуючи традиції Генделя та інших авторів каденцій.

Для зручності написання ми будемо іноді використовувати такі скорочення в сонатній формі: ГП - головна партія; ПП - побічна партія; ЗП - заключна партія та ВП - вступна партія.

Центральна частина циклу Larghetto, написана в тональності g-moll (тобто в паралельній тональності, пануючій в розробці першої частини циклу), - прекрасна лірична та скорботна хода на s. Її сонатна форма дуже близька до складної трьохчастинної.

Відкривається Larghetto вступом у фортепіано - базовим матеріалом для всієї частини та іiі тем. Основним інтонаційним мотивом вступної партії є поступовий низхідний хід, звернений та ритмічний варіант лейтінтонації Концерту, його синкоповано в збільшенні в провідній лінії і у баса, з повторністю кожного звуку. Цей лейтоборот набуває надалі важливу драматургічну роль. П’ять ланок секвенції на ньому завершуються кадансом з новим мелодійним оборотом (d) і зупинкою на домінанті.

Після фортепіанного вступу у арфи звучить головна тема Larghetto. В їі мелодійній основі знову-таки мотив лейтінтонації. Перший розділ - експозиція - досить незвичайного внутрішнього наповнення: a-в-с, тобто головна партія, побічна та заключна партії: 7 т. + 6 т. + 6т.

Перед побічною партією звучить зв'язка, аналогічна завершенню вступу, але в мажорному варіанті. Побічна партія характеризується 
гармонійними фігураціями імітаційного принципу викладу, з використанням «золотої секвенції». ПП звучить в паралельній тональності - B-dur (тональності крайніх частин).

Тема вступу виконує формотворчу роль у всій частині. 3'являється вона і на початку розробки, заснованої переважно на гармонічних фігураціях з теми ПП - знову в секвентному варіанті з використанням «золотої секвенціï». Тональний план розробки: d-moll, F-dur, d-moll, B-dur (тональності V, VII, V, III ступенів). У розробці знаходиться цікавий хоральний епізод в d-moll (тональність мінорної домінанти), що вносить відчутний фактурний контраст (цифра 3).

У репризі (два такти до цифри 4) тема вступу виконує особливо виразну роль: ії двутакти чергуються з чотиритактною темою головної партії (цифра 4). Але вже при появі теми головної партії, на вершинах акордів втручається вперше в творі мотив Dies irae (es-d-es-c). А після вторинного звучання теми вступної партії цей мотив вже не тільки впроваджується, але і затверджується в репризі (c-moll, g-moll).

Реприза включає знову збільшене навантаження на вступну партію, бо вона виконує формотворчу роль: звучать теми вступної, головної партій, знову вступної, побічної партій (6 тактів), заключної партії $(2+4)$. Тобто вступна тема передує звучанню як головної, так і побічної партій та виконує формостворюючу функцію.

Таким чином, основну роль у другій частині Концерту грає тема вступу, що вийшла з лейтмотиву першої частини та вбирає лейтмотив Dies irae.

Все зупиняється на домінантовій гармонії (традиційно)... I починається найважча для виконання блискуча Каденція арфи в якій постійними опорними точками є акорди g-moll, B-dur, g-moll, i після трьох динамічних хвиль призводить до коди. Знову чуємо тему вступу, що вийшла з лейтмотиву першої частини, і мотив Dies irae. Останній отримав важливу роль у частині, бо вступає в точці золотого перетину другої частини та всього Концерту.

Так і завершується середня частина. Три наступних такти Adagio розмикають будову та зупиняються на домінанті.

Цій частині Концерту властиві такі барочні риси, на які треба звернути увагу:

- інтонаційна структура;

- особливості нюансування;

- гармонічні особливості вертикалі;

• фігураційний рух; 
- лінеарність мислення;

- введення мотиву Dies irae;

- гармонічний, мелодичний та ритмічний зміст фактури твору.

Перекладення музики, написаної для різних (інших) інструментів, - процес творчий, що потребує напруженої інтелектуальної праці та знання особливостей (філософських, естетичних, музичних, технологічних) тієї епохи, до якої належить обрана нами музика. Тому під час перекладення з твором обов'язково відбувається певна трансформація.

Враховуючи обмеженість діапазону бандури, нам довелося дещо змінювати фактуру твору. Наприклад, акорди та октави в лівій руці (які призначені виконуватися лівою рукою) при інтерпретації на бандурі спрощуються до одноголосся (такти 7-14; 23-26; 34-37; 43; $45-50 ; 52-55 ; 57-72 ; 73-76 ; 79-83 ; 89-92 ; 109 ; 127-134)$.

Іноді ми змушені розподіляти музичну тканину твору між двома руками інакше, ніж це записано в оригіналі (такти $14 ; 16 ; 18 ; 38$; $40 ; 42)$.

Для зручності виконання деякі музичні фрази та мелодичні лінії були перенесені з однієї октави в іншу, враховуючи при цьому закономірності голосоведіння та руху мелодичної лінії твору (такти 15; 56; $57 ; 85-90)$.

Треба зазначити, що інтерпретуючи на бандурі твори середнього та високого ступеня складності, виконавець має досить вільно володіти харківським способом гри («перекидкою»). Так, в концерті даний спосіб гри зустрічається в $19-22 ; 28 ; 29 ; 34 ; 35 ; 44 ; 77 ; 78$ тактах.

Особливої уваги потребує каденція, оскільки має більш віртуозний характер. Зробимо ії виконавський аналіз більш детально. Звернемо увагу на те, що в тактах $76 ; 80-84 ; 99-102 ; 104-107 ; 109-111$ музична фактура в арфовому виконанні розподіляється рівномірно між двома руками, проте на бандурі ці «музичні фрагменти» можна виконати лише правою рукою. Певні складнощі виникають через численність в музичній фактурі даного фрагменту досить дрібних тривалостей, велику кількість альтерованих нот та швидкий темп.

Велике значення має вірно розставлена аплікатура (такти 76; 80 $84 ; 100-103 ; 105-108 ; 110-112 ; 114-126)$, оскільки музична тканина має насичену пасажну фактуру з участю поліритміки, яка викладається дрібними тривалостями, а саме: шістнадцятими; тридцять другими; квінтолями; секстолями та септолями, що вимагає легкого та «ажурного» звучання. 
Іноді гармонічне спрощення в лівій руці супроводжувалося перенесенням нижнього голосу акорду в іншу октаву, враховуючи особливості нашого інструменту (що змінює мелодичне положення акорду).

Партію лівої руки доводиться дещо змінювати (або максимально спрощувати), залишаючи лише сильну та відносно сильну долі четвертними тривалостями (такти 93-98), в той час як в оригіналі даний музичний фрагмент викладається шістнадцятими.

Таким чином, музично-виконавський аналіз «Концерту для органа (або арфи) та струнного оркестру В-dur» Г. Ф. Генделя, в перекладенні М. Г. Парфенова для арфи та фортепіано та перекладенні для бандури та фортепіано Я. Г. Пухальського, а також особливості трансформації партії арфи для бандури об'єктивно дають можливість зробити наступний висновок - перекладення арфових творів для бандури можливе. Такі перекладення значно збагачують репертуар для бандури, знайомлять виконавців та слухачів з музикою бароко, з ії інтонаційністю, тематизмом, гармонією, драматургічним наповненням, принципами розвитку, жанровими особливостями.

При тому музика бароко добре звучить в сучасності і в ії інтерпретації, подобається самим виконавцям, з підвищенням сприймається слухачами, віддаючи велику шану першоджерелам.

\section{СПИСОК ЛІТЕРАТУРИ}

1. Давидов М. Теоретичні основи перекладення інструментальних творів для баяна / М. Давидов. - К. : Музична Україна, 1977. - С. 98.

2. Давидов М. Історія виконавства на народних інструментах (Українська академічна школа) : підручник для вищих та середніх музичних навчальних закладів / М. Давидов. - К. : НМАУ імені П. І. Чайковського, 2005. - 419 с.

3. Давидов М. Теоретичні основи перекладення інструментальних творів для баяна / М. Давидов. - К. : Музична Украна, 1977. - 99 с.

4. Дейнега В. М. Перекладення як процес переосмислення засобів оркестрової виразності : автореф. дис. ... канд. мист-ва : спец. 17.00.03 «Музичне мистецтво / Володимир Миколайович Дейнега. - Одеса : ОДМА імені А. В. Нежданової, 2006. - 19 с.

5. Дмитрук I. І. Жанр перекладу та його різновиди в сучасному бандурному мистецтві : автореф. дис. ... канд. мист-ва : спец. 17.00.03 «Музичне мистецтво» / Ірина Іванівна Дмитрук. - Львів : ЛНМА імені М. В. Лисенка, 2009. $-18 \mathrm{c}$.

6. Дулова В. Искусство игры на арфе / В. Дулова. - М. : Советский композитор, 1975. - $228 \mathrm{c}$.

7. Дутчак В. Г. Розвиток професійних засад бандурного мистецтва 19701990 років. Творчість і виконавство : автореф. дис. ... канд. мист-ва : спец. 
17.00.03 «Музичне мистецтво / Віолетта Григорівна Дутчак. - К. : НМАУ імені П. І. Чайковського, 1996. - 24 с.

8. Овчарова С. В. До проблеми перекладення органних хоральних прелюдій Й. С. Баха в контексті динаміки подальшого розвитку сучасного бандурно-академічного репертуару / Овчарова С. // Матеріали Всеукр. наук.практ. конф. «Академічне народно-інструментальне мистецтво України». Дрогобич, 2007. - С. 124-125.

9. Хмель Н. В. Арфа та бандура - їх модифікація та порівняльна характеристика/ Н. В. Хмель // Музикознавча думка Дніпропетровщини : зб. наук. статей. - Дніпрпетровськ : Ліра, 2014. - Вип. 9. - С. 164-175.

10. Хмель Н. В. Специфика трансформации концерта с-moll Б. Марчелло - И. С. Баха в переложении для бандуры / Н. В. Хмель // Материалы Международной заочной научно-практической конференции «Филология, искусствоведение и культурология: актуальные вопросы и тенденции развития». - Новосибирск : СибАК, 2013. - С. 98-105.

Хмель Н. Особенности переложсения партии арфы для бандуры (на примере «Концерта для органа (или арфы) и струнного оркестра В-dиг» Г. Ф. Генделя). В статье предлагается музыкально-исполнительский анализ второй части «Концерта для органа или арфы и струнного оркестра B-dur» Г. Ф. Генделя в переложении для арфы и фортепиано Н. Г. Парфенова и переложении для бандуры и фортепиано Я. Г. Пухальского, а также рассматривается специфика трансформации партии арфы для бандуры.

Ключевые слова: теория исполнительства произведений эпохи барокко, арфа, бандура, переложение, трансформация, каденция.

Khmel' $N$. The features of harp party transcription for bandura (on example of «Concerto for organ (or harp) and string orchestra B-dur» by G. F. Handel). The musical and performing analysis of the second part of «Concerto for organ (or harp) and string orchestra B-dur» by G. F. Handel in transcription for harp and piano by M. G. Parfenov and setting for piano and bandura by J. G. Pukhalsky is presented in the article. Also an author considers the specificity of harp party transcription for bandura.

Key words: theory of performing works by baroque, harp, pandora, arrangement, transformation, cadence. 